\title{
Effects of Obesity on the Perioperative Results and Continence Status in Laparoscopic Radical Prostatectomy
}

\section{Obezitenin Laparoskopik Radikal Prostatektomide Peroperatif Sonuçlara ve Kontinansa Olan Etkisi} \author{
İsmet Yavaşçaoğlu1, Hakan Vuruşkan ${ }^{1}$ \\ 1 Uludağ University Faculty of Medicine, Department of Urology, Bursa, Turkiye \\ ${ }^{2}$ Aydın University Faculty of Medicine, Department of Urology, Istanbul, Turkiye \\ 3 Uludağ University Faculty of Medicine, Department of Pathology, Bursa, Turkiye \\ ${ }^{4}$ Koç University Faculty of Medicine, Department of Urology, Istanbul, Turkiye
}

Onur Kaygısız1, Çağdaş Gökhun Özmerdiven2, Berna Aytaç Vuruşkan³, Burhan Coşkun1, Kadir Ömür Günseren1, Yakup Kordan4,

\section{What's known on the subject? and What does the study add?}

In this study, we reviewed the outcomes of initial 300 surgeries. The results showed the obese patients can operated even at the early stages of the learning. The urinary continence rate in obese patients were lower than the others at $6^{\text {th }}$ month. However, these rates were similar at one year follow-up. There is more information regarding obesity and robot assisted prostatectomy according to laparoscopic radical prostatectomy. The series regarding laparoscopic radical prostatectomy and obesity have large number of patients or long ago studied. Therefore, the current study will provide additional information to the literature and will guide to the surgeons who are willing to perform laparoscopic radical prostatectomy.

\begin{abstract}
Objective: To assess the effects of obesity on the surgical success and perioperative results and continence status in laparoscopic radical prostatectomy (LRP).

Materials and Methods: The results of 300 consecutive patients undergoing LRP between April 2004 and January 2014 were analyzed retrospectively. Twenty patients were excluded from the study, thus, 280 patients remained. The patients were separated into 3 groups according to their body mass index. Based on this classification, group $1\left(<25 \mathrm{~kg} / \mathrm{m}^{2}\right)$ was normal, group $2\left(25-30 \mathrm{~kg} / \mathrm{m}^{2}\right)$ was overweight, and group $3\left(>30 \mathrm{~kg} / \mathrm{m}^{2}\right)$ was obese. The demographic data, intraoperative results, pathological results, and states of continence were compared among the groups.

Results: There were 81 patients in group 1, 152 patients in group 2, and 47 patients in group 3. There were no significant differences when the groups were compared according to age and prostate specific antigen values. The intraoperative blood loss was high in group 3 only. Moreover, the estimated blood loss, transfusion, operative time, bilateral nerve-sparing rate, hospitalization days, and complication rate were similar between the groups. There were no significant differences when the pathological results were compared according to the positive surgical margins and Gleason scores. Although the continence rates in group 3 were significantly low 6 months after the operation $(p<0.05)$, the results were similar at 1 year $(\mathrm{p}=0.738)$.
\end{abstract}

Conclusion: LRP can be applied confidently in obese patients as well as normal and overweight patients.

Keywords: Body mass index, laparoscopic surgery, obesity, prostatectomy

Öz

Amaç: Laparoskopik radikal prostatektomi (LRP) cerrahisinde obezitenin cerrahi başarı, perioperatif sonuçlara ve kontinansa olan etkisinin araştırılmasıdır.

Gereç ve Yöntem: Nisan 2004-Ocak 2014 tarihleri arasındaki 300 LRP uygulanan hastanın sonuçları retrospektif olarak incelendi. Yirmi hasta çalışma dışı bırakıldıktan sonra kalan 280 hasta çalışmaya alındı. Hastalar vücut kitle indeksine göre 3 gruba ayrıldılar. Grup 1: $<25 \mathrm{~kg} / \mathrm{m}^{2}$ olanlar

Correspondence: Onur Kaygısız MD, Uludağ University Faculty of Medicine, Department of Urology, Bursa, Turkiye Phone: +90 5053987959 E-mail: onurkygsz@yahoo.com ORCID ID: orcid.org/0000-0002-9790-7295

Received: 08.10 .2017 Accepted: 25.10 .2017

Cite this article as: Kaygısız O, Özmerdiven ÇG, Aytaç Vuruşkan BA, Coşkun B, Günseren KÖ, Kordan Y, Yavaşcaoğlu I, Vuruşkan H. Effects of Obesity on the Perioperative Results and Continence Status in Laparoscopic Radical Prostatectomy. J Urol Surg 2017;4:183-188. 
normal, $25-30 \mathrm{~kg} / \mathrm{m}^{2}$ olanlar kilolu ve $>30 \mathrm{~kg} / \mathrm{m}^{2}$ olanlar obez olarak sınıflandırıldı. Gruplar demografik veriler, intraoperatif sonuçlar, patoloji sonucu ve kontinans durumuna göre karşılaştırıldı.

Bulgular: Grup 1'de 81 hasta, grup 2'de 152 hasta, grup 3'te 47 hasta mevcuttu. Yaş ve prostat spesifik antijen sonuçlarına göre karşılaştırıldıklarında anlamlı fark bulunmadı. Intraoperatif hemogram kaybı anlamlı olarak obez grupta yüksek izlendi. Bununla birlikte tahmini kan kaybı, transfüzyon intiyacı, operasyon süresi, bilateral sinir koruyucu oranları ve hastanede yatış süresine göre karşılaştırıldığında sonuçları gruplar arası benzerdi. Gruplar komplikasyonlar açısından, Satava ve modifiye Clavien skorları ile karşılaştırıldığında, anlamlı fark görülmedi. Patoloji sonuçları, pozitif cerrahi sınır ve gleason skoruna göre karşılaştırıldığında anlamlı fark izlenmedi. Ameliyattan sonra 6. ayda obez grupta anlamlı olarak düşük izlenmesine rağmen, 1. yılda kontinans oranlarındaki sonuçlar benzerdi.

Sonuç: LRP normal kilolu ve aşırı kilolu hastalarla karşılaştıııldığında, obez hastalara da güvenle uygulanabilir.

Anahtar Kelimeler: Vücut kitle indeksi, laparoskopik cerrahi, obezite, prostatektomi

\section{Introduction}

Obesity is an important public health problem affecting a considerable part of Turkey's population. Over the last 20 years, the adult obesity prevalence in Turkey has increased significantly; while $18.8 \%$ of the adult population was obese in 1990 (women 28.5\%, men 9\%), the prevalence increased to 36\% in 2010 (women 44\%, men 27\%). In the future, this prevalence is expected to increase even more (1). In cases of obesity, not only the fat mass, but also the amount of the serum testosterone, estrogen, insulin, and insulin-like growth hormone-1 related to prostate cancer increase (2). In addition, obesity increases the mortality risk and the advanced disease risk in prostate cancer (3). Numerous studies are available regarding the effects of obesity on robot-assisted laparoscopic prostatectomy (RALP) and laparoscopic radical prostatectomy (LRP) surgeries. In some case series, the operation time, blood loss, and disease stage in obese patient groups were reported to increase $(4,5)$. However, in other studies, no effects on the intraoperative and early oncological periods were seen (6).

In this study, we evaluated the effects of obesity on the perioperative, intraoperative, oncologic, and continence results in patients undergoing extraperitoneal LRP.

\section{Materials and Methods}

After receiving approval from the Uludağ University Ethics Committee (approval number: 52588837-000/464), the results of 300 consecutive patients undergoing LRP between 2004 and 2014 were analyzed from the prospective radical prostatectomy database, retrospectively. Patients with concomitant bladder tumors $(n=1)$, unrecorded body mass index (BMI) $(n=5)$, those receiving adjuvant hormonal therapy $(n=10)$, shorter one year follow ups and followed up for less than 1 year $(n=4)$ were excluded from this study. Therefore, the 1-year follow-up results in 280 patients were analyzed. The BMI was scaled according to the World Health Organization recommendations, and the patients were separated into 3 groups according to their BMI. Group 1 was classified as having a normal weight (BMI $<25 \mathrm{~kg} /$ $\left.\mathrm{m}^{2}\right)$, group 2 was overweight $\left(\mathrm{BMI}=25-30 \mathrm{~kg} / \mathrm{m}^{2}\right)$, and group 3 was obese (BMI $>30 \mathrm{~kg} / \mathrm{m}^{2}$ ). Overall, 81 patients in group 1, 152 patients in group 2, and 47 patients in group 3 were included in this study. Age and prostate specific antigen (PSA) level were recorded as the preoperative findings, while hemogram results, estimated blood loss, transfusion need, operative time, bilateral nerve-sparing status, and pathological results, including the surgical margins, tumor grade end pathological stages, and complications, were recorded as the intraoperative findings. The Satava classification was used for intraoperative complications (7), and postoperative complications were analyzed with the modified Clavien classification (8). PSA values were obtained every 3 months, and continence status was evaluated every 6 months. The continence status of the patients was determined and registered to the database by an urologist who was not involved in primary surgical care of the patients. The patients were evaluated with detailed history, total urine examination, and post voiding residual volume for evaluation of incontinence. The total number of pads used in each day was questioned and the patients who were free of pad or using only one pad per day were considered as having social continence.

With regard to the surgical technique, a retroperitoneal space was created in the Trendelenburg position, and 5 ports were used in the procedure. Next, the retropubic space was created, the endopelvic fascia was incised, and the puboprostatic ligament was cut. The dorsal vein complex was ligated using a radiofrequency vessel-sealing device; then, the bladder neck was cut and a Benique bougie was used to apply traction to the prostate. The posterior seminal vesicle and vas deferens were dissected and cut. The Denonvilliers' fascia between the rectum and prostate was cut and dissected towards the apex of the prostate, and the neurovascular bundle in the laterals was controlled with a Weck clip, without cauterization. Neuron sparing was implemented according to the touch and biopsy results of the patient and the localization of the mass. The apex of the prostate and the urethra were dissected, the retrourethral muscles were cut and put into a specimen bag, and a urethrovesical anastomosis was created using the van Velthoven technique (9). Patients with a PSA >10 and Gleason 
score $>6$ underwent pelvic lymph node dissections. One week later, the catheter was removed. The pelvic floor exercises were instructed to all of the patients postoperatively for achievement of an early continent state.

\section{Statistical Analysis}

The statistical analysis was performed using SPSS version 23 software (SPSS Inc., Chicago, Illinois, USA). The Shapiro-Wilk's test was used to assess the normality of the continuous variables. Continuous variables that were not normally distributed were compared by using the Kruskal-Wallis One-Way ANOVA, while the normally distributed continuous variables were compared using an ANOVA. The nominal variables were compared with a chi-square test, and a $p$ value of lower than 0.05 was accepted as statistically significant.

\section{Results}

The average age of the patients was $63.9 \pm 5.6$ years, and there were no statistically significant differences among the groups $(p=0.33)$. In addition, there were no statistically differences in PSA level, bilateral nerve sparing rate, operative time, and hospitalization days between the groups (Tables 1, 2). Moreover, the estimated blood loss and blood transfusion rate were similar among the groups, however, the intraoperative hemoglobin losses were $-1.9(-6.5 /-0.5)$ in group $1,-1.9(-9.2 /-0.1)$ in group 2 , and $-2.6(-5.3 /-0.5)$ in group $3(p=0.035)$.

As an intraoperative complication, 1 patient in the overweight group underwent a laparoscopic repair during the same session due to a rectal injury. One patient from the normal weight group and 1 patient from the overweight group underwent open surgery due to postoperative rectal injuries. One patient from the overweight group was followed up in the intensive care unit on the $3^{\text {rd }}$ day because of sepsis and was discharged after reaching general wellness. All patients with postoperative complications classified as grade 1 according to the modified Clavien classification had wound site infections. Grade 2 patients, with the exception of 2 patients under treatment because of high fever in the overweight group, required transfusion because of bleeding. Overall, there were no differences in intraoperative and postoperative complications between the groups (Table 2).

The pathological results and postoperative continence states are indicated in Table 2. According to the pathological results, there were $54(66.7 \%)$ patients with organ-confined diseases pT2 in the normal group, 91 in the overweight group (59.9\%), and $24(51.1 \%)$ in the obese group. Locally advanced disease pT3 was observed in 27 patients (33.3\%) in the normal group, 61 patients (40.1\%) in the overweight group and 23 patients $(48.9 \%)$ in the obese group. Although more locally advanced disease patients were seen in the obese group, this was not statistically significant $(p=0.082)$. There were no statistically significant difference among the groups in terms of bilateral neuroprotective rate and positive surgical margins ( $p=0.353$ and $p=0.813$, respectively). In addition, there was no statistically significant difference in Gleason score between the groups $(p=0.917)$.

The incontinence rate was higher in the overweight and obese groups when compared to the normal group at the $6^{\text {th }}$ month of follow-up ( $p=0.04)$, but the rates were similar at the end of the 1 st year $(p=0.738)$. However, the continence rates were similar among the first 140 patients and the remaining 140 patients

Table 1. Comparisons of the demographic data and intraoperative results

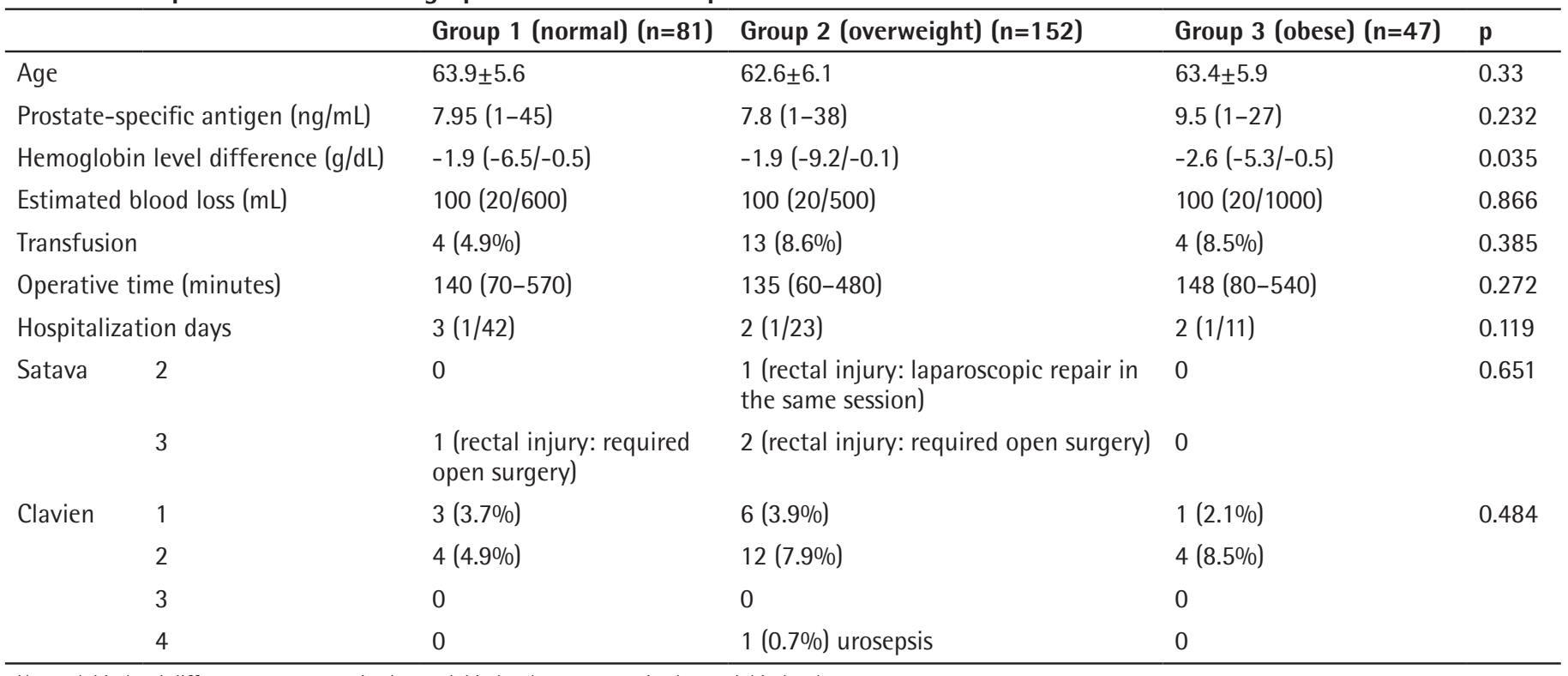

Hemoglobin level difference $=$ preoperative hemoglobin level - postoperative hemoglobin level 
Table 2. The tumor-node-metastasis classification of the pathological results after the laparoscopic radical prostatectomies, Gleason scores, and continence states

\begin{tabular}{|c|c|c|c|c|c|}
\hline & & $\begin{array}{l}\text { Group } 1 \text { (normal } \\
\text { weight) }(n=81)\end{array}$ & $\begin{array}{l}\text { Group } 2 \text { (overweight) } \\
(n=152)\end{array}$ & $\begin{array}{l}\text { Group } 3 \text { (obese) } \\
(n=47)\end{array}$ & $\mathbf{p}$ \\
\hline \multirow[t]{3}{*}{ Stage } & pT2 & $54(66.7 \%)$ & $91(59.9 \%)$ & $24(51.1 \%)$ & \multirow{3}{*}{0.082} \\
\hline & pT3 & $27(33.3 \%)$ & $61(40.1 \%)$ & $23(48.9 \%)$ & \\
\hline & $\leq 6$ & $49(60.5 \%)$ & $95(62.5 \%)$ & $30(63.5 \%)$ & \\
\hline \multirow[t]{2}{*}{ Gleason score } & 7 & $30(37.0 \%)$ & $47(30.9 \%)$ & $14(29.8 \%)$ & \multirow[t]{2}{*}{0.917} \\
\hline & $>7$ & $2(2.5 \%)$ & $10(6.6 \%)$ & $3(6.4 \%)$ & \\
\hline \multicolumn{2}{|c|}{ Surgical margin + } & $25(30.8 \%)$ & $42(27.6 \%)$ & $15(31.9 \%)$ & 0.813 \\
\hline \multicolumn{2}{|c|}{ Bilateral nerve sparing + } & $31(38.3 \%)$ & $72(47.3 \%)$ & $20(42.6 \%)$ & 0.353 \\
\hline \multicolumn{2}{|c|}{ Incontinence rate after 6 months } & $10(12.3 \%)$ & $42(27.6 \%)$ & $15(31.9 \%)$ & 0.04 \\
\hline \multicolumn{2}{|c|}{ Incontinence rate after 1 year } & $3(3.7 \%)$ & $9(5.92 \%)$ & $3(6.38 \%)$ & 0.738 \\
\hline
\end{tabular}

when compared regarding their weight status at the $6^{\text {th }}$ month of follow-up.

\section{Discussion}

In this study, the effects of obesity on LRP were investigated. In a study evaluating the effect of BMI on pathological and functional outcomes following open radical prostatectomy, an increase in the complication rates and disruptions in function and continence was observed, especially in groups of obese and overweight patients (10). As opposed to open surgery, clinical studies about the effects of obesity on LRP have reported that obesity extends the operative time and increases blood loss. However, in contrast with open radical prostatectomy, the complication and function rates were similar to those of normal weight patients $(4,5)$.

Brown et al. (11) stated that the operative time was longer in obese patients because of the long dissection, anastomosis, and port implantation times. In addition, there could be a longer extraperitoneal space preparation time and more difficulty in conveying the medical instruments to the depth of the pelvis (4). In previous RALP studies, the operative time was longer in obese patients and similar to that of laparoscopic surgery $(12,13,14)$. In a robotic surgery, wider spaces are required to be able to move the robot's arms in a more comfortable way; thus, these processes are conducted intraperitoneally. The time is also longer in a robotic surgery because the space is limited, since obese patients have more fat in the pelvic area (15). In our study, we found that the average operative time in obese patients was not statistically significant, but was 8-13 minutes longer. We believe that the preparation of the extraperitoneal space and difficulty in conveying the laparoscopic hand tools to the depth of the pelvis extended the time.

In one study comparing the complications between obese and normal and overweight patients undergoing LRP, there were similar complication rates according to the Clavien classification
(5). In our study, when the groups were compared according to the modified Clavien classification, one patient had urosepsis, however, there were no differences between the groups. Sundi et al. (6) compared LRP and RALP in 193 prostate cancer cases, and they determined that the operative time in the LRP group was longer, but the complication rates were similar. In another study, it was observed that the complication rate in the RALP group was higher (12).

Many studies have shown that the average blood loss, which is another parameter affected by obesity, was higher in obese patients than in those of normal weight $(4,5,10)$. Eden et al. (16) especially indicated that obesity and blood loss were interrelated, which may be due to lack of experience. In contrast with LRP surgeries, the average blood loss in patients having normal weights was similar to that in obese patients undergoing RALP surgery $(6,17)$. In our study, the average blood loss and transfusion needs in normal weight, overweight, and obese patients were similar. However, the hemoglobin reduction was higher in obese patients, which could be the reason for the hemodilution related to the intravenous fluid injection during the postoperative period (15). Brown et al. (11) monitored postoperative hemoglobin loss in obese and non-obese groups and indicated no statistically significant difference.

Amling et al. (18) stated that obese patients developed prostate cancer at younger ages and in advanced stages, however, another series showed that the average ages and PSA levels were not statistically different $(4,5)$. In our study, there was no statistically significant difference in PSA levels between normal and obese patients. According to a study by Mitchell et al. (19), obesity increased the risk of advanced disease, but PSA can not be used as a foresight criterion for showing the tumor burden in patients having high BMI.

It has been reported that the aggressive disease encountered in many of the studies was seen more often in obese patients $(18,20,21)$. Chronic inflammation, hypoxia induced by obesity, 
and defects in the immune functions are the presumed reasons for this situation (22). Especially, pT3 disease and Gleason scores over 7 were statistically high $(5,6,23,24)$. Lower PSA levels due to the greater body areas in obese patients and late diagnoses have been suggested to be reasons for a more aggressive and advanced stage disease (21). In our study, when considering the pathological results, the advanced-level disease pT3 rate was high, but the results were statistically similar to those in the other groups. The possibility of local recurrence was observed to increase up to 50\% over five years with a Gleason score over 7, pT3 disease, and positive surgical margins. Therefore, positivity of the surgical margins constitutes a considerable part of the surgery (25). Freedland et al. (3) reported 30\% surgical margin positivity for the normal weight patients and $45 \%$ for the obese patients in a 1.106-case series. In addition, Campeggi et al. (4) observed 27\% surgical margin positivity for their obese patients. They stated that although aggressive disease was observed in obese patients, the reasons for the surgical margin positivity were iatrogenic. Gözen et al. (5) attributed the high level of surgical margin positivity in obese patients to aggressive disease. In our study, the surgical margins among the three groups were similar.

Patients with a BMI of $>25$ exhibited a higher rate of incontinence after RALP and open radical prostatectomy procedures $(10,26)$. According to one meta-analysis, in terms of the criteria determining urinary incontinence after an RALP, a high BMI was one of the most important criteria in determining incontinence (27). In addition, obese patients were reported to have weaker urinary function, with the inefficacy of the neuroprotective surgery and sutures being reported as the reason. Gu et al. (15) observed that there were no differences between obese group and the other groups according to the analysis they conducted at the $3^{\text {rd }}$ and $12^{\text {th }}$ months after RALP. Moreover, Eden et al. (16) determined that there were no differences in continence between obese and normal weight patients after LRP. According to a study by Wiltz et al. (28), the continence rates in obese patients in their $1^{\text {st }}$ and $2^{\text {nd }}$ years in an RALP series were low. In our study, we observed that the significantly high incontinence levels in the overweight and obese patients during the first 6 months of follow-up were similar to those in the other groups at the end of the 1 st year. We believe that this depends on the sphincter tonus recovery over time.

\section{Study Limitations}

The limitation of this study was its retrospective design. However, the data were collected prospectively with a standard data sheet, which could have minimized the potential bias.

\section{Conclusion}

During our 1-year follow-up, the complications, oncological results, and continence in normal, overweight, and obese patients undergoing LRP surgery were similar. However, the incontinence rate was higher in overweight and obese patients during the first 6 months. Despite its difficulty when compared with normal weight patients, LRP surgery can be implemented with confidence in obese patients.

\section{Ethics}

Ethics Committee Approval: The study was approved by the Uludağ University Local Ethics Committee (approval number: 52588837-000/464).

Informed Consent: Retrospective study.

Peer-review: Externally peer-reviewed.

\section{Authorship Contributions}

Surgical and Medical Practices: B.A.V., H.V., Y.K., I.Y., Concept: O.K., Ç.G.Ö., Y.K., H.V., Design: O.K., Ç.G.Ö., Data Collection or Processing: O.K., Ç.G.Ö., B.C., K.Ö.G., Analysis or Interpretation: O.K., Literature Search: O.K., Ç.G.Ö., B.C., Writing: O.K., Ç.G.Ö.

Conflict of Interest: No conflict of interest was declared by the authors.

Financial Disclosure: The authors declared that this study received no financial support.

\section{References}

1. Erem C. Prevalence of Overweight and Obesity in Turkey. IJC Metabolic \& Endocrine 2015;8:38-41.

2. Freedland SJ, Aronson WJ. Examining the relationship between obesity and prostate cancer. Rev Urol 2004;6:73-81.

3. Freedland SJ, Terris MK, Presti JC Jr, Amling CL, Kane CJ, Trock B, Aronson WJ; Search Database Study Group. Obesity and biochemical outcome following radical prostatectomy for organ confined disease with negative surgical margins. J Urol 2004;172:520-524.

4. Campeggi A, Xylinas E, Ploussard G, Ouzaid I, Fabre A, Allory Y, Vordos D, Abbou CC, Salomon $L$, de la Taille A. Impact of body mass index on perioperative morbidity, oncological, and functional outcomes after extraperitoneal laparoscopic radical prostatectomy. Urology 2012;80:576584.

5. Gözen AS, Akin Y, Özden E, Ates M, Hruza M, Rassweiler J. Impact of body mass index on outcomes of laparoscopic radical prostatectomy with longterm follow-up. Scand J Urol 2015;49:70-76.

6. Sundi D, Reese AC, Mettee LZ, Trock BJ, Pavlovich CP. Laparoscopic and robotic radical prostatectomy outcomes in obese and extremely obese men. Urology 2013;82:600-605.

7. Satava RM. Identification and reduction of surgical error using simulation. Minim Invasive Ther Allied Technol 2005;14:257-261.

8. Dindo D, Demartines N, Clavien PA. Classification of surgical complications: a new proposal with evaluation in a cohort of 6336 patients and results of a survey. Ann Surg 2004;240:205-213. 
9. Van Velthoven RF, Ahlering TE, Peltier A, Skarecky DW, Clayman RV. Technique for laparoscopic running urethrovesical anastomosis: the single knot method. Urology 2003;61:699-702.

10. Mandel P, Kretschmer A, Chandrasekar T, Nguyen HG, Buchner A, Stief CG, Tilki D. The effect of BMI on clinicopathologic and functional outcomes after open radical prostatectomy. Urol Oncol 2014;32:297-302.

11. Brown J, Rodin DM, Lee B, Dahl D. Laparoscopic Radical Prostatectomy and Body Mass Index: An Assessment of 151 Sequential Cases. J Urol 2005;173:442-445.

12. Ahlering TE, Eichel L, Edwards R, Skarecky DW. Impact of obesity on clinical outcomes in robotic prostatectomy. Urology 2005;65:740-744.

13. Mikhail AA, Stockton BR, Orvieto MA, Chien GW, Gong EM, Zorn KC, Brendler CB, Zagaja GP, Shalhav AL. Robotic-assisted laparoscopic prostatectomy in overweight and obese patients. Urology 2006;67:774-779.

14. Castle EP, Atug F, Woods M, Thomas R, Davis R. Impact of body mass index on outcomes after robot assisted radical prostatectomy. World J Urol 2008;26:91-95.

15. Gu $\mathrm{X}$, Araki M, Wong C. Does elevated body mass index (BMI) affect the clinical outcomes of robot-assisted laparoscopic prostatectomy (RALP): a prospective cohort study. Int J Surg 2014;12:1055-1060.

16. Eden CG, Chang CM, Gianduzzo T, Moon DA. The impact of obesity on laparoscopic radical prostatectomy. BJU Int 2006;98:1279-1282.

17. Kim MJ, Park SY, Rha KH. Influence of prostate weight, obesity and height on surgical outcomes of robot-assisted laparoscopic radical prostatectomy in Korean men. J Robotic Surg 2008;1:287-290.

18. Amling CL, Kane CJ, Riffenburgh RH, Ward JF, Roberts JL, Lance RS, Friedrichs PA, Moul JW. Relationship between obesity and race in predicting adverse pathologic variables in patients undergoing radical prostatectomy. Urology 2001;58:723-728.

19. Mitchell CR, Umbreit EC, Rangel U, Bergstralh EJ, Karnes RJ. Does Body Mass Index "Dilute" the Predictive Property of Prostate-specific Antigen for Tumor Volume at Radical Prostatectomy? Urology 2011;4:868-872.

20. Calle EE, Rodriguez C, Walker-Thurmond K, Thun MJ. Overweight, obesity, and mortality from cancer in a prospectively studied cohort of US adults. N Engl J Med 2003;348:1625-1638.
21. Morote J, Celma A, Planas J, Placer J, Konstantinidis C, Iztueta I, de Torres IM, Oliván M, Reventós J, Doll Al. Sedentarism and overweight as risk factors for the detection of prostate cancer and its aggressiveness. Actas Urol Esp 2014;38:232-237.

22. De Pergola G, Silvestris F. Obesity as a major risk factor for cancer. J Obes 2013;2013:291546.

23. Gong Z, Agalliu I, Lin DW, Stanford JL, Kristal AR. Obesity is associated with increased risks of prostate cancer metastasis and death after initial cancer diagnosis in middle-aged men. Cancer 2007;109:1192-1202.

24. Parker AS, Thiel DD, Bergstralh E, Carlson RE, Rangel $\sqcup$, Joseph RW, Diehl N, Karnes RJ. Obese men have more advanced and more aggressive prostate cancer at time of surgery than non-obese men after adjusting for screening PSA level and age: results from two independent nested case-control studies. Prostate Cancer Prostatic Dis 2013;16:352-356.

25. Hanks GE. External beam radiation therapy for clinically localized prostate cancer: patterns of care studies in the United States. NCI Monogr 1988:7584.

26. Sugaya $K_{1}$ Oda $M$, Nishijima $S$, Shimabukuro $S$, Ashimine $S$, Sunabe $T$, Shimabukuro H, Goya M, Kagawa $H$, Yonoh H, Shiroma K, Miyazato T, Koyama $Y$, Hatano T, Ogawa $Y$, Owan T. Risk factors for duration of urinary incontinence after radical prostatectomy. Nihon Hinyokika Gakkai Zasshi 2002;93:444-449.

27. Ficarra V, Novara G, Ahlering TE, Costello A, Eastham JA. Graefen M, Guazzoni G, Menon M, Mottrie A, Patel VR, Van der Poel H, Rosen RC, Tewari AK, Wilson TG, Zattoni F, Montorsi F. Systematic review and meta-analysis of studies reporting potency rates after robot-assisted radical prostatectomy. Eur Urol 2012;62:418-430.

28. Wiltz AL, Shikanov S, Eggener SE, Katz MH, Thong AE, Steinberg GD, Shalhav $A L$, Zagaja GP, Zorn KC. Robotic radical prostatectomy in overweight and obese patients: oncological and validated functional outcomes. Urology 2009;73:316-322. 